\title{
Building Professional Competencies Indices in the Solar Energy Industry for the Engineering Education Curriculum
}

\author{
Chin-Guo Kuo ${ }^{1}$ and Chi-Cheng Chang ${ }^{2}$ \\ ${ }^{1}$ Department of Industrial Education, National Taiwan Normal University, No. 162, Section 1, Ho-Ping East Road, Taipei 106, Taiwan \\ ${ }^{2}$ Department of Information Management, Lunghwa University of Science and Technology, No. 300, Section 1, Wanshou Road, \\ Guishan, Taoyuan County 333, Taiwan
}

Correspondence should be addressed to Chi-Cheng Chang; chig@mail.lhu.edu.tw

Received 21 March 2014; Accepted 16 April 2014; Published 29 April 2014

Academic Editor: Ho Chang

Copyright (c) 2014 C.-G. Kuo and C.-C. Chang. This is an open access article distributed under the Creative Commons Attribution License, which permits unrestricted use, distribution, and reproduction in any medium, provided the original work is properly cited.

\begin{abstract}
This study aims to develop professional competency indices and their subindices as needed by the solar energy industry, to establish a basis for development of the engineering education curriculum. The methodologies adopted by the study are literature analysis, expert advisories, and focus groups. The study focuses on the establishment of competency indices by experts at stock market-listed companies and then confirms these competencies with focus groups. The study found that the competencies required by the solar industry consist of knowledge, skills, and attitudes in the areas of materials development and applications, photovoltaic technology, cell manufacturing technology, biotechnology, chemical technology, power generation and electricity, process development and improvement, data collection and analysis, industry regulation, green energy beliefs, and working attitudes and values. The results of this study can be used as the basis for the cultivation, selection, and employment of industry professionals.
\end{abstract}

\section{Introduction}

Green energy is an important industrial sector in this era of international competition. This energy sector includes (1) the main industries of solar photovoltaic and LED lighting and (2) the general potential industries of wind power, biofuels, hydrogen and fuel cells, energy information and communication, and electric vehicles among others [1]. The solar energy industry is one of the most important "green energy" industries. The output value of Taiwan's solar industry as a whole is expected to exceed 15 billion NTD in 2015, with the silicon solar cell module accounting for much of it, at the same time as it ranks number 4 in the world [1]. The maintenance of international competitiveness and sustainable development in the industry in the future will mainly depend on the quality of the industry's human resources. How to provide the professional competencies needed by the industry and to further develop curricula to nurture talent are the core priorities of engineering education.

Research into the solar industry in the past has focused primarily on several different but related areas, including business strategy, scientific knowledge and technology, tools and software applications, processes, and optimisation development. For example, in the area of business strategy, Chang and Kuo [2] studied two sets of dynamic business competencies needed in the industry; in the technical area, there was a study of Kuo et al. [3]. In professional competencies and solar energy competency standards and applications, O'net [4] established 51 industrial competency standards. Although there are not many studies focusing on how to teach energy technologies in engineering education, there is still energy education research related to ecology by Acikgoz [5] and the literature of solar energy education investigated by Dalitz et al. [6]. In summary, solar industry engineer training studies mainly take competence-based and resourcebased perspectives. Competence-based approaches can help build the core competencies of solar business professionals, so that enterprises can develop their core competencies with market segmentation. In terms of business strategy, resource-based approaches regard the professional talents of solar industry engineers as one of an enterprise's core resources, on the basis of which maximum benefit may be 
generated from the competitive market for the organisation, through the domination and appropriate allocation of resources.

In recent years, the solar industry has had to adapt to an ultracompetitive environment. An enterprise's competitive advantage derived from resource strength is quickly eroded as a result of its competitors' technological innovations $[7,8]$. Moreover, the operations of international companies in the solar industry generally focus on the vertical integration of the supply chain, while Taiwan's manufacturers mostly focus on specialised manufacturing $[9,10]$. In view of the rapid changes in the technical content of a business's technologies, and since Taiwan's advantages are in manufacturing, one of the biggest problems of engineering education is how to keep up with the changes in the professional competencies required by the industry and how to plan and design the curricula needed to foster the talent required for industrial development. Therefore, to establish a basis for the solution of this problem, this study aims to establish professional competency indices and their subindices for the solar energy industry. The research may contribute, firstly, as a basis for the planning and designing of the curriculum for the training of engineers in higher education and, secondly, in the industrial sector, as an important reference for enterprises needing to select, train, and utilise their human resources or to cultivate management's successors.

\section{Theoretical Background}

The solar industry requires highly talented professionals. Competence-based and resource-based theories have been regarded as two important approaches to supporting the competency and developing the talent of professionals working in the solar industry. Only if workers have the appropriate competencies can they perform their tasks satisfactorily, making competency extremely important [11, 12]. "Competency," here, can be defined as a prerequisite for a particular occupation, or a set of performance standards, as well as the ability to complete the work/task [13]. In competence-based theory, I-O psychologists generally take the competency model formed by KSAOs (Knowledge, Skill, Ability, Others) as a suitable way to describe the critical capabilities required for performing a particular job [14]. Therefore, "Competency" can also be regarded as the set of capabilities that you should have when engaging in a particular task [15]. This competency can be further subdivided into general competency, management competency, professional competency, and core competency [16]. With the professional competency expected by the employer establishing a baseline, the techniques and skills exhibited by technical personnel allow prediction of their job performance $[17,18]$.

The resource-based approach regards professional talent as a rare, unique, irreplaceable but intangible asset of the solar industry, on the basis of which the competitive advantage of the enterprise can be created [19]. In other words, the resource-based approach considers the unique resources within the enterprise as the fundamental source of competitive advantage of solar industry enterprises but with the talent of the individual engineers working there forming the core of this unique resource [2]. When an individual possesses the professional competencies required for performing his job, he owns the resources value desired by the enterprise, allowing him to be hired from the labour market. Therefore, following Sandberg and Pinnington [13], this study defines professional competencies as a set of capabilities possessed by university graduates allowing them to successfully perform the task when engaged in professional missions in the field of solar energy.

\section{Dimensions of Professional Competency}

In their study of solar company executives, Chang and Kuo [2] pointed out that solar executives should have a common core of dynamic competencies listed as follows: environmental sensing competencies, learning absorption competency, social networking competencies, and coordination and integration competencies. In addition, particular dynamic competencies required will include competency in discerning market growth momentum, competency in mastering market timing, and competency in changing or creating customer demand. Meanwhile, from the route of structuralism, the various dimensions of professional competency, as seen by the engineering education certification standards of ABET [20], include the important core competencies of problem solving, innovation, and information competency. The problem of competency gaps that these different approaches throw up was explored by Abdullah et al. [21] with their advocating of the idea of soft and hard skills, the former including ICT skills, personal qualities, thinking skills, interpersonal skills, management skills, and communication skills. Cilliers [22] regarded that these soft skills should also include "ability to produce reports," while the hard skills should include "practical usage of software tools," "circuit construction," "operating and troubleshooting systems and equipment," "process, control, and installation," and "quality and reliability testing". On the other hand, in "Solar Energy Systems Engineers", O'net [4] lists the titles of this job, ten major tasks of engagement required by the job, and data collected for each competency application including tools and technology, interests, work values, wages, and employment trends.

In summary, based on the 51 competency standards in O'net [4] and the work of Cilliers [22], Kuo and Sheen [23], Abdullah et al. [21], and others, this study drafted 11 professional competencies (with their subcompetencies) as follows: materials development and application competency, photovoltaic technology competency, cell manufacturing technology competency, biotechnology competency, chemical technology competency, power generation and power competency, process development and improvement competency, data collection and analysis competency, regulation competency, green energy beliefs competency, and work attitudes and values competency. 
TABLE 1: The expert sampling list of Taiwan's solar enterprises.

\begin{tabular}{|c|c|c|c|c|}
\hline Distribution & Business item & The number of manufacturers & $\%$ & The size of sample collected (\%) \\
\hline Upstream & $\begin{array}{l}\text { Silicon materials, silicon } \\
\text { wafer materials }\end{array}$ & 17 & 13.93 & $8(47.06 \%)$ \\
\hline \multirow[t]{6}{*}{ Midstream } & & 47 & 38.51 & $16(34.04 \%)$ \\
\hline & Solar cell & 15 & 12.30 & \\
\hline & Solar cell module & 18 & 14.73 & \\
\hline & Thin film solar cell module & 9 & 7.38 & \\
\hline & Dye-sensitized solar cell & 3 & 2.46 & \\
\hline & $\begin{array}{l}\text { Concentrating solar cell } \\
\text { module }\end{array}$ & 2 & 1.64 & \\
\hline \multirow[t]{4}{*}{ Downstream } & & 58 & 47.56 & $21(36.21 \%)$ \\
\hline & Solar PV system & 39 & 31.98 & \\
\hline & Solar PV power converter & 10 & 8.20 & \\
\hline & Solar PV access/supplier & 9 & 7.38 & \\
\hline Total & & 122 & 100 & $45(100 \%)$ \\
\hline
\end{tabular}

\section{Methodology}

4.1. Literature Analysis. The aim is through literature analysis to obtain the professional competencies and subcompetencies that should be possessed by working solar engineers, as a basis for expert advisories and expert focus group discussion.

4.2. Expert Advisory. As they show the point of view of the enterprises employing engineers, the aim of the expert advisory is to establish the professional competency dimensions and to obtain the professional competencies required of working engineers, as expressed by company representatives. Samples were ten Taiwan solar companies listed on the stock market, two upstream in the solar raw materials industry, five midstream in the solar manufacturing industry, and three downstream in the solar module and integration industry, with subjects interviewed coming from middle and upperlevel management.

4.3. Focus Group Method. The aim is to edit the draft subcompetencies developed for each professional competency dimension. The composition of expert groups is shown in Table 1. In terms of sampling, of the total existing 122 Taiwan solar manufacturers, representatives from the upstream solar raw materials industry (e.g., pure metals, iron and titanium alloys and other metal materials, and silicon chip production); the midstream solar manufacturing industry (e.g., amorphous silicon thin film solar cells and modules; monocrystalline and polycrystalline silicon solar cells and modules; silicon solar cells and modules; polysilicon solar cells and modules; and silicon thin film solar cells), and the downstream solar module and integration industry (e.g., small-scale solar power systems, solar electric power converters, and solar power systems) were gathered. In three focus group meetings, industrial and academic experts were jointly invited to discuss the draft, with the invited industrial experts coming from manufacturers with a scale of more than 30 employees, and totalling 45 experts as working-level heads. From academia, nine scholars within the field were also invited to participate in the discussion.

\section{Results and Discussion}

This study found that solar industry professional competency is composed of 11 professional dimensions, with each professional competency composed of several subdimensions, as shown in Table 2. In the application of research methods in response to a need to establish the professional competencies required in an industry, the DACUM (Develop A Curriculum) method is usually used, with the experts using brainstorming techniques to obtain the needed professional skill directory/listing [24]. On the other hand, in the Delphi method, the experts' anonymous input is used to seek advisory consistency between the professional competency and its subcompetencies [25]. In the V-tech method, the enterprise survey emphasises a large sample within a single industry to get a list of general professional competencies needed for engagement in the specific professional career [26]. This study adopted the expert advisory method, emphasising qualitative expert interviews through close contact with benchmark solar companies listed on the stock market. Together with the focus group method, through discussions with solar industry experts, the professional competencies and their subcompetencies in the solar industry were thus confirmed. Therefore, the research method adopted by this study can essentially be regarded as an application of the DACUM method.

In terms of subcompetencies, the professional engineers sought in the solar job market not only necessarily possess technical knowledge and hard skills but also need soft skills. The talent to develop materials and processes that satisfy market demand is composed of soft and hard skills [27, 28]. Each competency dimension and subdimension obtained by this study are composed of three fields, namely, knowledge, skill, and attitude. Moreover, all the important soft skills are also fully covered in the study, at the same time as both the 
TABLE 2: The solar professional competency dimensions and connotations.

Dimension

(1) Materials development and application competency

(2) Photovoltaic technology competency

(3) Cell manufacturing technology competency

(4) Biotechnology competency

(5) Chemical technology competency

(6) Power generation and power competency

(7) Process development and improvement competency

(8) Data collection and analysis competency

(9) Regulation competency

(10) Green energy belief competency

(11) Work attitudes and values
Competency connotation

(1) Understand the materials development process

(2) Understand the solar cell principle

(3) Understand solar light-absorbing material type and characteristic differences

(4) Understand polymer characteristics and energy development

(5) Understand the polymer application technology

(1) Understand the principles of solid state physics

(2) Understand the characteristics of semiconductor materials

(3) Understand core photovoltaic technology

(4) Understand the main problems of the solar industry

(5) For solar industry issues, be able to propose solutions

(1) Understand solar cell material type and characteristic differences

(2) Analyse the application relationship between cell type and energy

(3) Understand the industry's process and packaging technology

(4) Understand the technology of cell manufacturing

(1) Have integrated the interdisciplinary knowledge of the solar industry

(2) Understand the concepts of energy and renewable energy

(3) Understand the application of relevant energy and renewable energy knowledge

(4) Be able to apply relevant knowledge of energy and renewable energy

(5) Understand the relations between solar panel power generation and the environment

(1) Understand the principles of chemistry, physical chemistry, analytical chemistry, and organic chemistry

(2) Understand interdisciplinary engineering-related processes

(3) Have constructed an energy integration platform

(4) Understand materials analysis techniques

(5) Understand physical and chemical technologies

(1) Understand monitor principles

(2) Understand solar panel principles

(3) Understand the principles and structure of solar power generation

(4) Understand the relevant principles of solid state physics

(5) Understand thin film technology

(1) Understand the key technology of packaging materials

(2) Understand the relevant principles of process development

(3) Be able to apply relevant knowledge to improve processes

(4) Have skills in assembly technology of solar products

(5) Possess knowledge of industrial safety and health principles

(1) Understand the principles of industrial safety

(2) Understand the principles of environmental pollution prevention and control

(3) Be able to explain solar cell and energy efficiency and carbon reduction relationships

(4) Know how to collect and analyse data on demand

(5) Understand the represented significance of data

(1) Understand relevant solar power policies

(2) Understand relevant renewable energy policies

(3) Understand the renewable energy incentives

(1) Be engaged in enhancing self-skills, professional knowledge

(2) Identify with green beliefs

(3) Possess the desire to implement environmental protection, sustainable management, and development measures

(4) Identify with solar power industry professional advancement, enabling promotion of green energy industry development

(1) Have a sense of mission and a passion for work

(2) Have positive work values

(3) Exhibit a positive professionalism

(4) Have a sense of integrity and business ethics

(5) Embody the spirit of innovation and research 
mental model and system concepts are adopted [29], in line with the requirement to foster professional talent.

\section{Conclusions}

Although international competition in green energy is fierce, fuelled by a demand for human technology that will achieve global ecological sustainability, the industry still attracts universal attention. Since talent is the force that drives industrial development, this study selected the industry, and solar energy in particular, as the topic of research. The study is grounded in competence-based and resource-based theories, regarding solar energy professionals to be the important human resource of enterprises, and understanding they need to possess various basic competencies to perform their job duties. Therefore, this study selected benchmarking enterprises that are listed on the stock market from the upstream, midstream, and downstream sectors of the Taiwanese solar energy industry as the source of its expert advisories for its professional competency dimensions, coupled with focus group meetings to establish professional solar industry subcompetencies. In summary, this study found 11 professional competencies, with subcompetencies, which can be regarded as professional standards required by university graduates to become working professional engineers.

In terms of practical applications, the results of this study can be used as selection criteria for enterprises in the field of solar energy for the further development of their staff or as professional-level assessment criteria for recruitment and promotion. In the area of university education, the results of this study can be also used as a basis for planning and designing curricula for programs in renewable and sustainable energy. In the future, the implementation of such curricula is expected to nurture the talent appropriate to the needs of the solar industry, benefitting the industry by closing the gap between those needs and the present competencies of university graduates. Therefore, this study specially demonstrates the contributions to engineering education associated with a concentration on the solar industry's training needs, at the same time as it benefits the industry's own selection and employment need.

As for research restrictions, the study only focuses on professional competencies common to all solar enterprises and does not focus on professional competencies required by specific enterprises upstream, midstream, or downstream. This study also did not explore the subcompetencies of a single solar expertise, that of process design, software and hardware technologies, and tools applications. We invite interested researchers to carry out further studies.

\section{Conflict of Interests}

The authors declare that there is no conflict of interests regarding the publication of this paper.

\section{Acknowledgments}

The authors acknowledge the financial support of NSC 1023113-S-003-008-G and NSC 102-3113-S-262-001.

\section{References}

[1] MOEAEC, "Green energy industry information net," 2014, http://www.taiwangreenenergy.org.tw/.

[2] C. C. Chang and C. G. Kuo, "Exploring dynamic capabilities of executives of solar product manufacturers," African Journal of Business Management, vol. 7, no. 40, pp. 4188-4198, 2013.

[3] C. G. Kuo, C. F. Yang, M. J. Kao et al., "An analysis and research on the transmission ratio of dye sensitized solar cell photoelectrodes by using different etching process," International Journal of Photoenergy, vol. 2013, Article ID 151973, 8 pages, 2013.

[4] O’net, "17-2199.11-Solar Energy Systems Engineers," 2014, http://www.onetonline.org/link/summary/17-2199.11.

[5] C. Acikgoz, "Renewable energy education in Turkey," Renewable Energy, vol. 36, no. 2, pp. 608-611, 2011.

[6] R. Dalitz, P. Toner, and T. Turpin, VET and the Diffusion and Implementation of Innovation in the Mining, Solar Energy and Computer Games Sectors, Department of Education, Employment and Workplace Relations, Australian Government, 2011.

[7] H.-Y. Liu and C.-W. Hsu, "Antecedents and consequences of corporate diversification: a dynamic capabilities perspective," Management Decision, vol. 49, no. 9, pp. 1510-1534, 2011.

[8] C. C. Chang, "An IPA-embedded model for evaluating creativity curricula," Innovations in Education and Teaching International, vol. 51, no. 1, pp. 59-71, 2014.

[9] MIC, "Outlook for the Global Emerging Solar Photovoltaic Market, 2011 Recap and 2012 Forecast," Market Intelligence \& Consulting Institute, 2014, http://mic.iii.org.tw/english/store/ en_3_mic_store_1_2_1.asp?doc_sqno=9010.

[10] C. G. Kuo, C. F. Yang, L. R. Hwang, and J. S. Huang, "Effects of titanium oxide nanotube arrays with different lengths on the characteristics of dye-sensitized solar cells," International Journal of Photoenergy, vol. 2013, Article ID 650973, 6 pages, 2013.

[11] Z. Lim, C. Anderson, and S. McGrath, "Professional skills development in a resource-poor setting: the case of pharmacy in Malawi," International Journal of Educational Development, vol. 32, no. 5, pp. 654-664, 2012.

[12] C. C. Chang, "Improving employment services management using IPA technique," Expert Systems with Applications, vol. 40, no. 17, pp. 6948-6954, 2013.

[13] J. Sandberg and A. H. Pinnington, "Professional competence as ways of being: an existential ontological perspective," Journal of Management Studies, vol. 46, no. 7, pp. 1138-1170, 2009.

[14] F. J. Landy and J. M. Conte, Work in the 21st Century, McGrawHill, New York, NY, USA, 2004.

[15] C. C. Chang, "Exploring IT entrepreneurs' dynamic capabilities using Q-technique," Industrial Management \& Data Systems, vol. 112, no. 8, pp. 1201-1216, 2012.

[16] D. Hellriegel, S. E. Jackson, and J. W. Slocum, Management: A Competency Based Approach, Winter Ventures, Hanover, Pa, USA, 1998.

[17] S. J. Hysong, "The role of technical skill in perceptions of managerial performance," Journal of Management Development, vol. 27, no. 3, pp. 275-290, 2008.

[18] C. C. Chang, "Building an approach to evaluate capabilities development," Pensee Journal, vol. 76, no. 1, pp. 167-179, 2014.

[19] J. B. Barney, "Firm resources and sustained competitive advantage," Journal of Management, vol. 17, no. 1, pp. 99-120, 2000.

[20] ABET, "Criteria for accrediting engineering programs 20122013," 2013, http://www.abet.org/DisplayTemplates/DocsHandbook.aspx?id=3143. 
[21] A. G. K. Abdullah, S. H. Keat, M. H. Abdullah, and M. Purba, "Mismatch between higher education and employment in Malaysian electronic industry: an analysis of the acquired and required competencies," International Journal of Engineering Education, vol. 28, no. 5, pp. 1232-1242, 2012.

[22] C. B. Cilliers, "Student perception of academic writing skills activities in a traditional programming course," Computers \& Education, vol. 58, no. 4, pp. 1028-1041, 2012.

[23] C.-G. Kuo and B.-J. Sheen, "Seaweed chlorophyll on the lightelectron efficiency of DSSC," Journal of the Chinese Chemical Society, vol. 58, no. 2, pp. 186-190, 2011.

[24] O. Gazman, "Industry-based skills standards for building operators-a business case," Strategic Planning for Energy and the Environment, vol. 32, no. 3, pp. 25-38, 2013.

[25] R. L. Jacobs and M. J. Bu-Rahmah, "Developing employee expertise through structured on-the-job training (S-OJT): an introduction to this training approach and the KNPC experience," Industrial and Commercial Training, vol. 44, no. 2, pp. 75-84, 2012.

[26] C. Dede, "Emerging influences of information technology on school curriculum," Journal of Curriculum Studies, vol. 32, no. 2, pp. 281-303, 2000.

[27] H. Baytiyeh, "Disparity between college preparation and career demands for graduating engineers," Journal of Engineering Education, vol. 28, no. 5, pp. 1221-1231, 2012.

[28] P. C. Huang, C. H. Huang, M. Y. Lin, C. Y. Chou, C. Y. Hsu, and C. G. Kuo, "The effect of sputtering parameters on the film properties of molybdenum back contact for CIGS solar cells," International Journal of Photoenergy, vol. 2013, Article ID 390824, 8 pages, 2013.

[29] C. Capelo and J. F. Dias, "A feedback learning and mental models perspective on strategic decision making," Educational Technology Research and Development, vol. 57, no. 5, pp. 629644, 2009. 

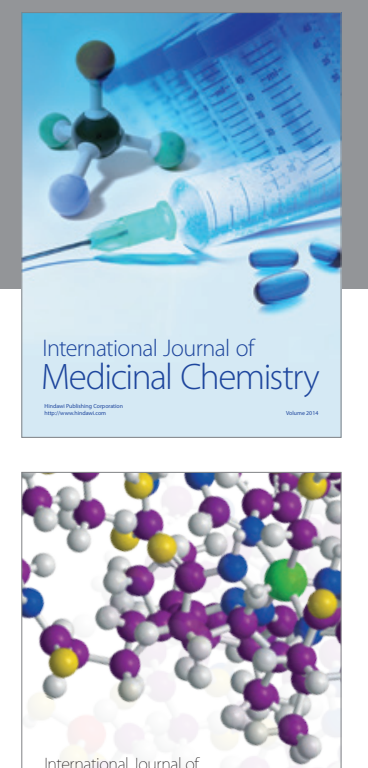

\section{Carbohydrate} Chemistry

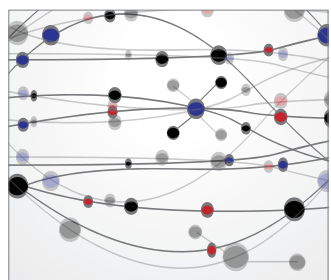

The Scientific World Journal
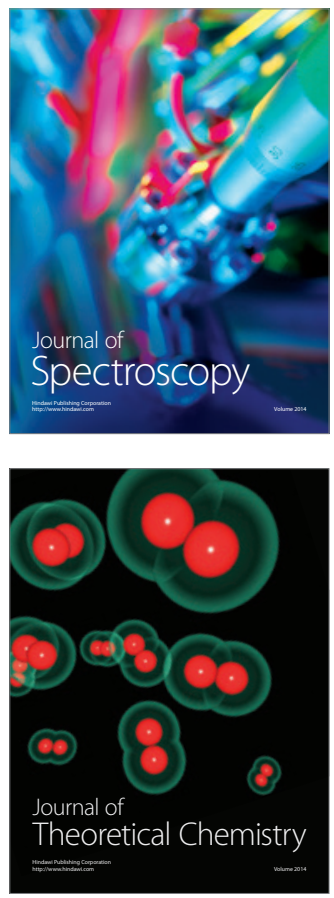
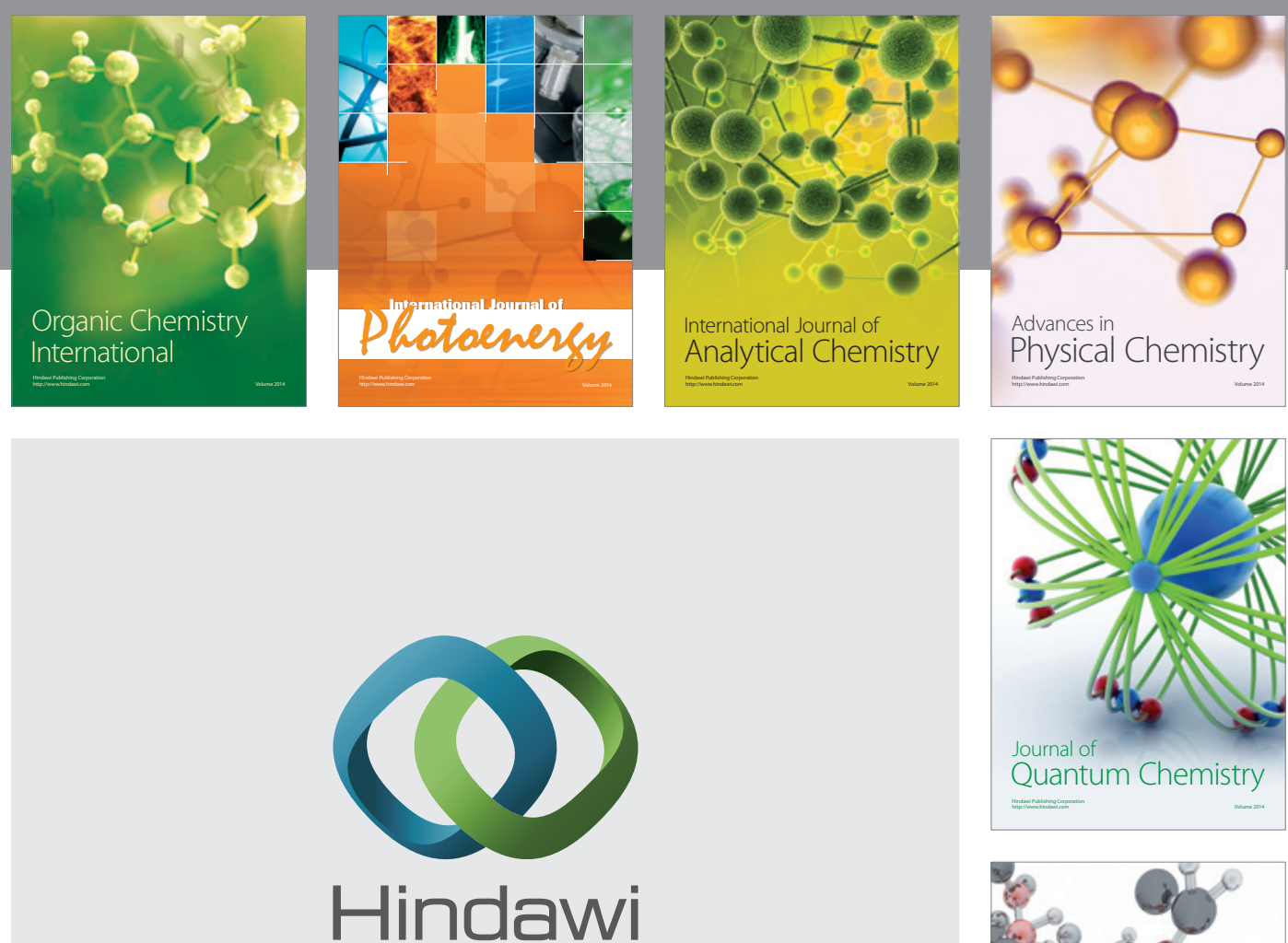

Submit your manuscripts at

http://www.hindawi.com

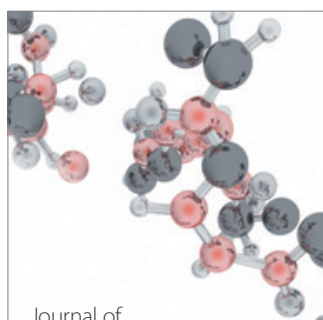

Analytical Methods

in Chemistry

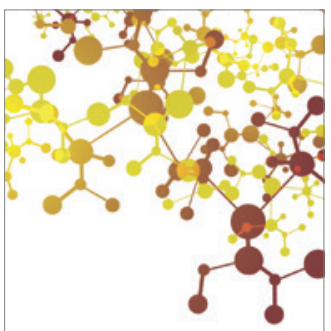

Journal of

Applied Chemistry

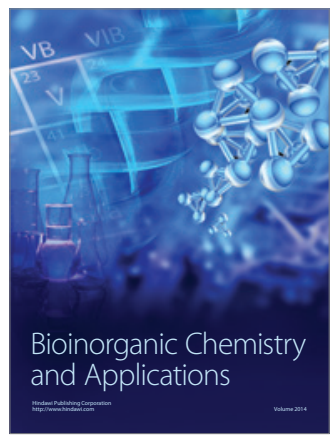

Inorganic Chemistry
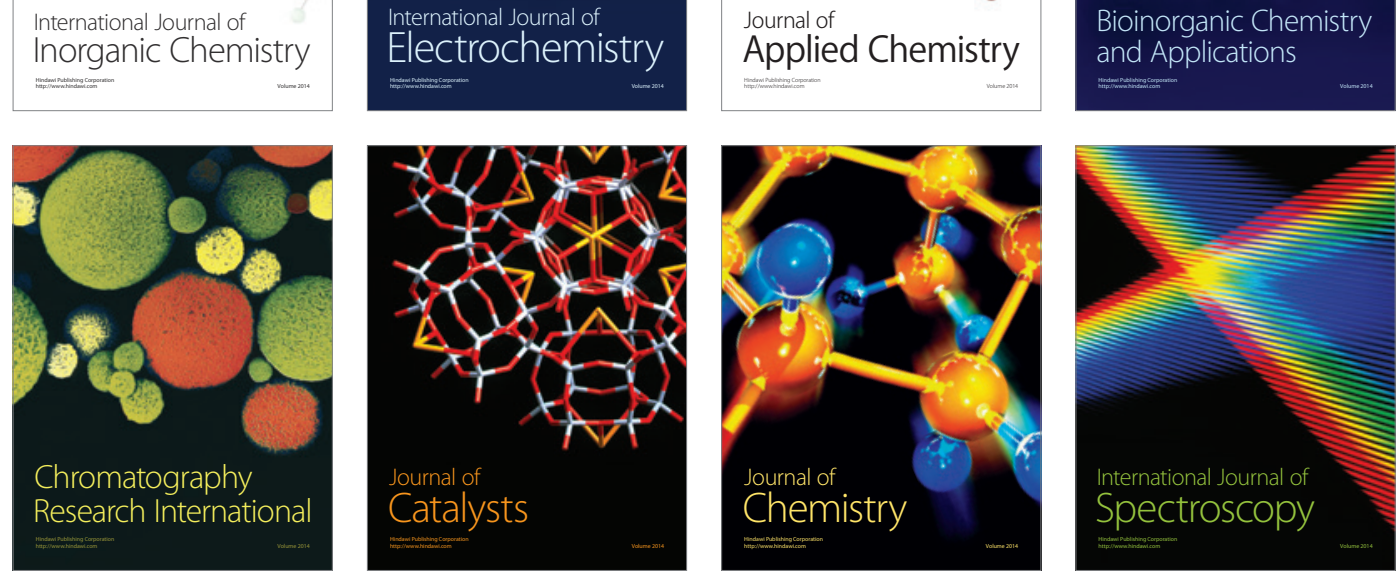